\title{
UVODNIK
}

\section{ŽENSKE, MIR IN VARNOST OB 15. OBLETNICI SPREJETJA RESOLUCIJE VARNOSTNEGA SVETA ORGANIZACIJE ZDRUŽENIH NARODOV 1325}

31. oktobra 2000 je Varnostni svet Organizacije Združenih narodov (OZN) sprejel Resolucijo $1325^{1}$ o ženskah, miru in varnosti. Sledile so ji še druge $(1820,1888,1889$, 1960, 2106, 2122 in 2422), ki poudarjajo nesorazmeren vpliv vojn in konfliktov na ženske in otroke ter osvetljujejo dejstvo, da so bile ženske zgodovinsko vedno na obrobju mirovnih procesov in stabilizacijskih naporov. Poudarjajo pomembno vlogo žensk pri preprečevanju in reševanju konfliktov, $v$ mirovnih pogajanjih, pri graditvi miru ter humanitarnih in pokonfliktnih aktivnostih. Resolucija 1325 poziva države članice, naj vključijo vidik spola v načrtovanje, priprave in usposabljanje za mirovne misije ter v sisteme obveščanja in programe OZN, predvsem naj zaščitijo ženske in deklice v oboroženih spopadih. Resolucijo je sprejela tudi naša država in Slovenska vojska jo je kot obvezno čtivo vgradila $\mathrm{v}$ programe usposabljanja in priprave slovenskih kontingentov, ki sodelujejo v mednarodnih operacijah in na misijah.

V Sloveniji sta po osamosvojitvi leta 1991 izšla dva zbornika, namenjena ženskam v oboroženih silah. Prvi je nastal leta 1995, pet let pred resolucijo OZN. Njegova urednica je bila Zorica Bukinac, založilo ga je Ministrstva za obrambo, naslov pa je Ženske v oboroženih silah. Leta 2002 je nastal drugi. Urednici sta bili Ljubica Jelušič in Mojca Pešec, moči so združili Obramboslovni raziskovalni center Fakultete za družbene vede, Ministrstvo za obrambo in Generalštab SV. V prvem zborniku smo dobili prvi opis ženskih izkušenj iz SV ter poglede domačih in tujih avtorjev na vlogo žensk v oboroženih silah. V drugem so bili z vidikov tradicije, kulture in vzorcev spolnih vlog predstavljeni omejevalni dejavniki pri vključevanju žensk v oborožene sile ter analiza deleža žensk in dolžnosti, ki jih opravljajo v SV.

Vizvirniku Security Council Resolution on Women Peace and Security, 1325. 
Večje vključevanje žensk v oborožene sile še vedno vzbuja veliko pozornosti in vprašanj. Izkušnje številnih držav so zelo različne, veliko je pozitivnih, pa tudi negativnih.

Leta 2015 je minilo 15 let od nastanka Resolucije 1325 o ženskah, miru in varnosti, 20 let od nastanka prvega zbornika in 13 let od nastanka drugega. V uredniškem odboru smo želeli s tematsko številko preveriti, kaj je novega na področju resolucije doma in po svetu, in to objaviti. K sodelovanju smo povabili podpolkovnico dr. Suzano Tkavc, svetovalko na področju vidika spola v Generalštabu SV, imenovano tudi za koordinatorico za enakost spolov na Ministrstvu za obrambo in nacionalno predstavnico $\mathrm{v}$ Natovem odboru za vidik spola. Z združenimi močmi je nastala številka, ki je pred vami.

Pablo Castillo Díaz, ki je zaposlen v Organizaciji združenih narodov, je pripravil članek z naslovom Pripadnice oboroženih sil v mirovnih operacijah in politika Resolucije 1325 Varnostnega sveta OZN. V njem z nami deli svoj strokovni pogled in izkušnje z vidika resolucije o ženskah, miru in varnosti, pri čemer s poudarkom na mednarodnih operacijah in misijah opozarja na prednosti in pomanjkljivosti resolucije.

Garry McKeon je napisal članek z naslovom Boljši državljani - usposabljanje s področja humanitarnosti in spola EUTM Somalija. Avtor je več kot 30 let pripadnik Irskih oboroženih sil, med drugim je sodeloval tudi na misiji v Somaliji. Njegove izkušnje pri usposabljanju za uresničevanje Resolucije 1325 so zelo zanimive, saj gre za kulturno okolje, ki se precej razlikuje od našega.

V članku z naslovom Nekatere dobre prakse s področja vidika spola in uresničevanja Resolucje VS OZN 1325 v 25-letnem obdobju SV avtorice Suzane Tkavc dobimo vpogled v obravnavo vidika spola v obdobju samostojnosti slovenske države, predvsem s poudarkom na oboroženih silah in njihovih aktivnostih v mednarodnih operacijah in na misijah. Kako dobro smo se pri tem izkazali glede na predstavnice in predstavnike vojsk drugih držav?

Dosežki in stališča pri izvajanju Resolucije VS OZN 1325 na Ministrstvu za obrambo in v Vojski Srbije je naslov članka avtoric Jovanke Šaranović, Brankice Potkonjak-Lukić in Tatjane Višacki. V Srbiji so si za uresničevanje Resolucije 1325 zelo prizadevali, saj je področje vključeno v nacionalni akcijski načrt. Pri tem sodeluje veliko različnih državnih organov in drugih nevladnih ustanov. Avtorice v članku ugotavljajo, kako uspešni so pri tem.

V članku z naslovom Analiza in ocena Resolucije VS OZN 1325 - kakšna so priporočila za priložnosti $v$ prihodnje nas Jane Derbyshire seznanja s pogledom na področje resolucije in z izkušnjami z vidika Obrambnih sil Nove Zelandije. So te zelo drugačne od izkušenj drugih držav? Avtorica meni, da je zdaj čas za spremembe. 
V primerjavi z večino avtorjev, ki so predstavniki oboroženih sil ali pa so z njimi neposredno povezani, je Nadja Furlan Štante članek z naslovom Ženske voboroženih silah: med nasiljem in ranljivostjo napisala z drugačnega vidika. Specializirana za religijske in ženske študije izhaja iz bioloških, zgodovinskih, religijskih in drugih vidikov, hkrati pa upošteva tudi ugotovitve, prakso in dela avtorjev, ki pišejo o področjih obrambe in oboroženih sil.

Verjamemo, da smo s to tematsko številko posredovali nove izkušnje in prispevali poglede $\mathrm{v}$ dinamičen mozaik vidika spola, spodbudili koga $\mathrm{k}$ branju in morda tudi $\mathrm{k}$ pisanju. 